This item was submitted to Loughborough's Research Repository by the author.

Items in Figshare are protected by copyright, with all rights reserved, unless otherwise indicated.

\title{
Sex in the sun: racial stereotypes and tabloid news
}

PLEASE CITE THE PUBLISHED VERSION

PUBLISHER

(C) Routledge (Taylor \& Francis Group)

VERSION

AM (Accepted Manuscript)

LICENCE

CC BY-NC-ND 4.0

REPOSITORY RECORD

Pickering, Michael. 2019. "Sex in the Sun: Racial Stereotypes and Tabloid News". figshare. https://hdl.handle.net/2134/5420. 
This item was submitted to Loughborough's Institutional Repository (https://dspace.lboro.ac.uk/) by the author and is made available under the following Creative Commons Licence conditions.

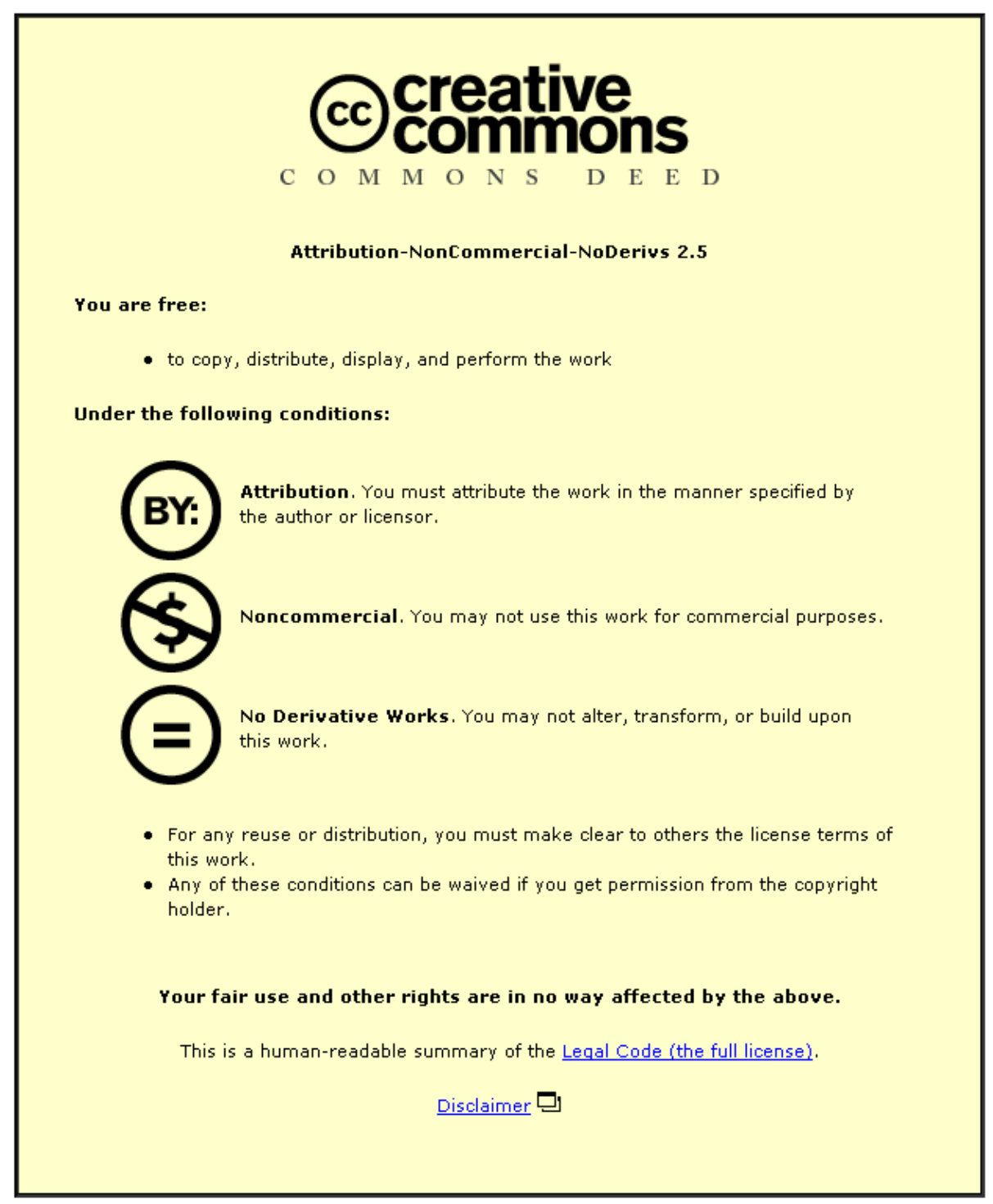

For the full text of this licence, please go to: http://creativecommons.org/licenses/by-nc-nd/2.5/ 


\section{SEX IN THE SUN: RACIAL STEREOTYPES AND TABLOID NEWS.}

\section{MICHAEL PICKERING}

Black men are pearls in beauteous ladies' eyes

\section{Two Gentlemen of Verona}

One of the paradoxes of the news is that they are not new at all. News reporting is always about some recent event, but the manner in which reporting occurs conforms to long-established values and practices. This is a widely acknowledged feature of news journalism. Numerous studies have shown how it deals in short-term changes through narrative codes, formats and genres which change only on a gradual basis. In forms of discourse that focus on the transient and fleeting developments that fly up from one day and one week to the next, certain enduring ways of depicting other people or cultures are readily facilitated by news conventionalism. In this way the regularised production routines and the familiar structures of news discourse which account for the high degree of standardisation in news stories are conducive to the reproduction of various forms of stereotype, even when particular individuals are identified and named.

Stereotypes are closely suited to the ways news handles what is temporally proximate through stock narrative templates. They are similarly paradoxical because they appear to operate as essentialist markers and reductive fixities in direct relation to current events and issues, but are in most cases figures of representation with long tentacular roots into the past. They seem to 'fit the moment' yet at the same time are actively residual elements of broad historical configurations of social encounter, order, domination and control. Their resilience and periodic reappearance are what are most remarkable, rather than their immediate manifestations in any specific instance of news construction and narration. ${ }^{1}$

We have of course to attend to this resilience, at least in part, through such immediate manifestations, and in doing so in this article I want to show how the durability of stereotypical figures and associations is given new support and impetus by being redressed and updated through the details supplied by a particular 'of the moment' story. ${ }^{2}$ The story was given frontpage prominence in a tabloid newspaper of the last decade of the twentieth century (see fig. 1). It concerned adultery and the abandonment of her husband and family home by a middle-aged white woman, Sandra Anderson, who fell in love with a young black man, Sagnia Bakary, while on holiday in Sarrakunda, a Gambian seaside resort, having gone to him initially for horse-riding lessons. The Sun, Britain's leading tabloid at the time, made this its lead story for Monday $7^{\text {th }}$ February 1994, giving it priority over all the other available stories for this particular edition. ${ }^{3}$ These included the massacre of 68 people in Sarajevo, attacks on John Major's premiership as leader of the Tory party, even a nude hang-glider landing on the roof of Buckingham Palace. These were all written up in the inside pages but not given the top treatment reserved for this

\footnotetext{
${ }^{1}$ On stereotypes, see Pickering, 2001, 2004a, 2004b and 2007; see also Allport, 1954, Bhabha, 1997, chapter 3, and Hinton, 2000.

${ }^{2}$ The analytical method on which this article is loosely based is set out in Deacon et al., 2007, chapters 7 and 8.

${ }^{3}$ See Chippindale and Horrie, 1990 for a general account of the development of the Sun's tabloid journalism.
} 
story about interracial sex and a broken marriage. The story was elaborated over one and a half pages inside the newspaper (see Figs 2 and 3).

\section{Structure of the Text}

Aside from its front-page status, the importance attached to the story was emphasised by three textual features: first, the banner headline consisting of two-inch black capital letters, and contrasting with the other headlines on the front page, which were either in colour, white, lowercase or smaller font; second, the 'Sun Exclusive' tag given to the story; and third, the use of a

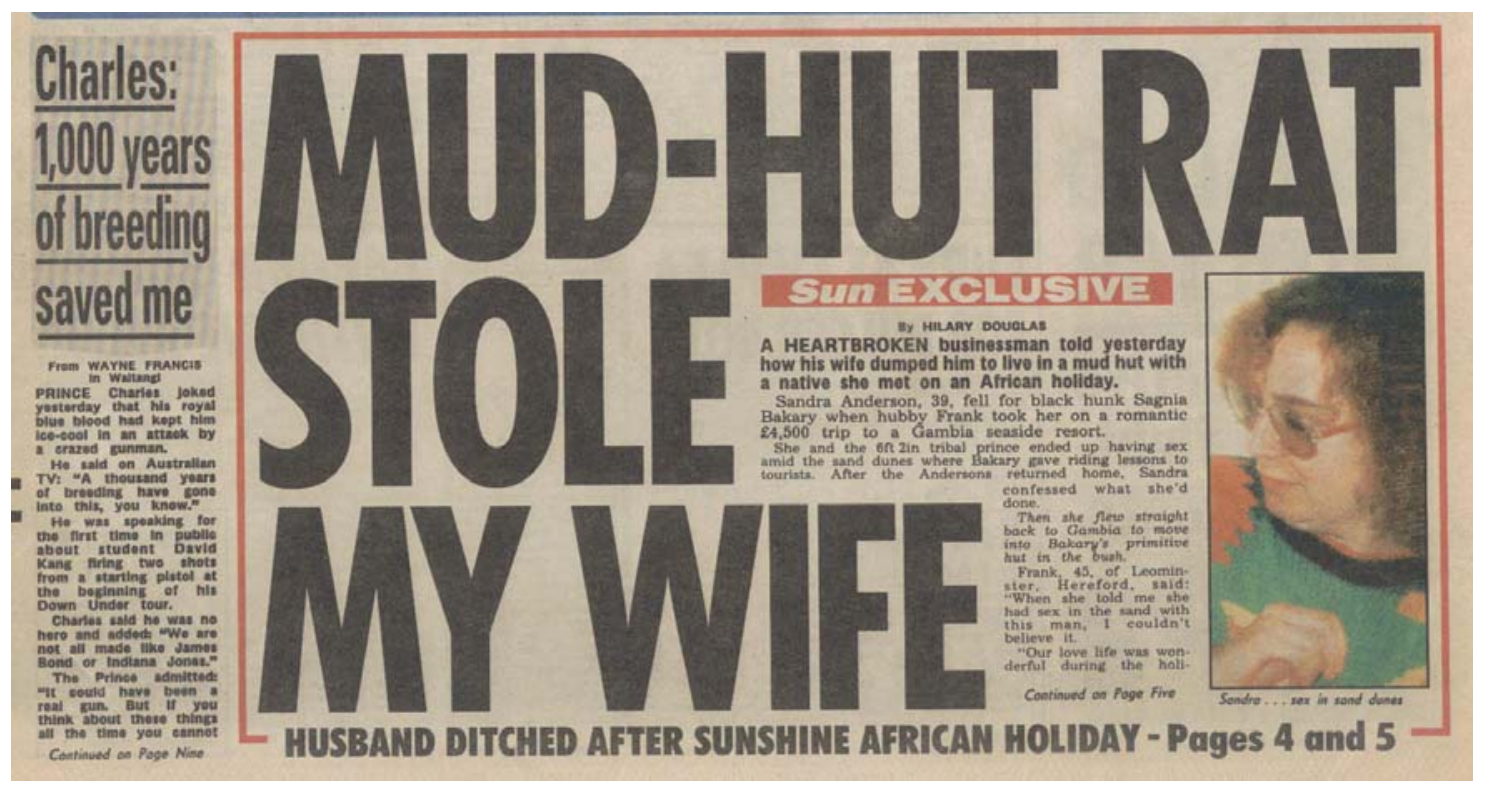

Fig. 1 Bottom half of front page of the Sun for Monday $7^{\text {th }}$ February, 1994.

photo illustration of the woman in the story, which again contrasts with the other story included on the front page. While the story was placed on the bottom half of the front page, it attained centrality because of the words 'MUD-HUT RAT', which figure in the centre of the page, immediately attracting the eye and leading straight through to the succeeding words 'STOLE MY WIFE'. The banner headline was wrapped around the initial paragraph of the story, itself given emphasis by the bold font: 'A HEARTBROKEN businessman told yesterday how his wife dumped him to live in a mud hut with a native she met on an African holiday'. Following the conventional pyramidal structure of news narrative, this short paragraph contained the gist of the story, giving further meaning to the headline and the subsidiary headline at the bottom of the page: 'Husband Ditched After Sunshine African Holiday'. The compositional centrality of the paragraph in the story's layout, surrounded by the headline and image of the woman in question, reinforced its narrative centrality, its quality as the nucleus of the story. This condensed the general theme of the story into its most significant components, with the overall organisation of the story gelling around it as it informed the rest of the narrative. In providing the story with its centrally unifying thread, the combination of main headline, subsidiary headline and lead paragraph asserted the key interpretative cue for the reader. 
In basic form this is all that needed to be known about the narrative, which was in effect brought to closure by its initiating elements. At the same time these elements also staked out the grounds on which the stereotyping would proceed in the remainder of the story. There are various ways in which this operated. To begin with, the first phrase in the primary juxtaposition of words in the banner headline - 'Mud-Hut Rat' - related to the usual colloquial expression 'love rat' often used in The Sun at this time (and subsequently) in its stories of celebrity sex and the extramarital affairs of famous people, as for example with the English rugby player Will Carling. It could be argued that the familiarity of the phrase at the time meant that there was no need to use the word 'love' in association with it, but dropping the first half of this diametrically contrasting term can also be seen as having supported the racially informed core of the narrative. If the expression 'love rat' is usually used in a metaphorical sense, the association with 'mud huts' reestablished some of the literal meaning of the epithet 'rat' in that vermin are to be expected in rudimentary or 'primitive' conditions, conditions which are stereotypically associated with 'native life' in sub-Saharan Africa. These were made abundantly clear as the story unfolded. The husband in the story was quoted as saying: 'She just didn't seem to care that he [the 'love rat'] lived in a horrible mud hut with no loo and just a charcoal fire to cook on'. The point was then given further emphasis: 'I couldn't believe that my wife, who always loved shopping and money, was going off to live in virtual squalor. They sleep on the floor over there. Hygiene is virtually non-existent'. The woman herself, Sandra Anderson, was also quoted as saying that she was happy despite her new home having no running water and the toilet consisting of 'an open cesspit in the garden', but this newfound happiness was played down in contrast to her steep descent from clean, respectable, English suburbia to 'mud-hut squalor'.

In the lead headline, the opposed categories of 'rat' and 'wife' were linked by the verb 'stole'. This had a pivotal position in the composition of the opening headline. It imparted a sense of activeness to the transition from wife to mistress, from responsible mother to sex-crazed concubine, though with blame being attributed to the 'thief', Sagnia Bakary, the self-styled African prince. The transition-as-descent theme that was central to the racist stereotyping of the story was buttressed at the outset by the secondary oppositions in the lead paragraph between 'businessman' and 'native', and even more strongly in the second paragraph between 'hubby Frank' and 'black hunk'. These oppositions were maintained throughout the story, as further detail made clear that 'hubby Frank' (the term of endearment giving emphasis to his assigned position as the wronged party) was a financially secure and dedicated owner of a landscaping enterprise in Leominster. The landscaped garden he had presumably created at his large Herefordshire home would have been utterly at odds with a mud hut and small attachment of land containing a 'hole-in-the-ground' loo. Such oppositions, and the attribution of blame for what had happened, need to be understood in relation to a further dimension of the discourse schema. This is concerned with the sourcing and sequencing of citation in the narrative.

There was more or less an equality of treatment in the number of quotations attributed to husband and wife in the story. Roughly nine column inches were given over to statements from each of them. The equilibrium this appeared to create across the opposed 'voices' of each party was clearly undermined by their narrative sequencing. All the quotes from Sandra Anderson were contained in the supplementary section on page four. Narrative priority and pre-eminence was given to the husband rather than the adulterous wife who had 'dumped' him after 22 years of marriage. It was his side of the story which came first. Its sequencing not only gave it greater accreditation but also provided an interpretative frame through which the woman's statements were cited and set up to be assessed. The apparent equilibrium between the protagonists' 'voices' in the story was subverted even more by the glaring absence of anything ascribed to Sagnia Bakary. His side of the story was ignored completely, with the implication that he was not worth consulting or worse, not worthy of being consulted. The news story condemned him to narrative 
silence. The 'voices' in the story were thus graded according to gender and ethnicity in the following way:

* Frank's (white male) side of the story. This followed directly from, and was directly implicated in, the nucleus of the story on page one. It was reinforced by further citation on page five. His was the first and last 'voice' heard in the story.

* Sandra's (white female) side of the story. This was introduced only on an inside page (see Fig. 2) and so sandwiched in between what her husband had to say. It was also undercut by the thematic structure of the news narrative as a whole.

* Sagnia's (black male) side of the story. This was entirely missing. The narrative denied him any focalised viewpoint and rendered him, from the story's perspective, speechless. Instead, and in contrast to the two white protagonists, he was racially labelled as the 'black hunk' who 'stole' someone out of a state of holy matrimony.
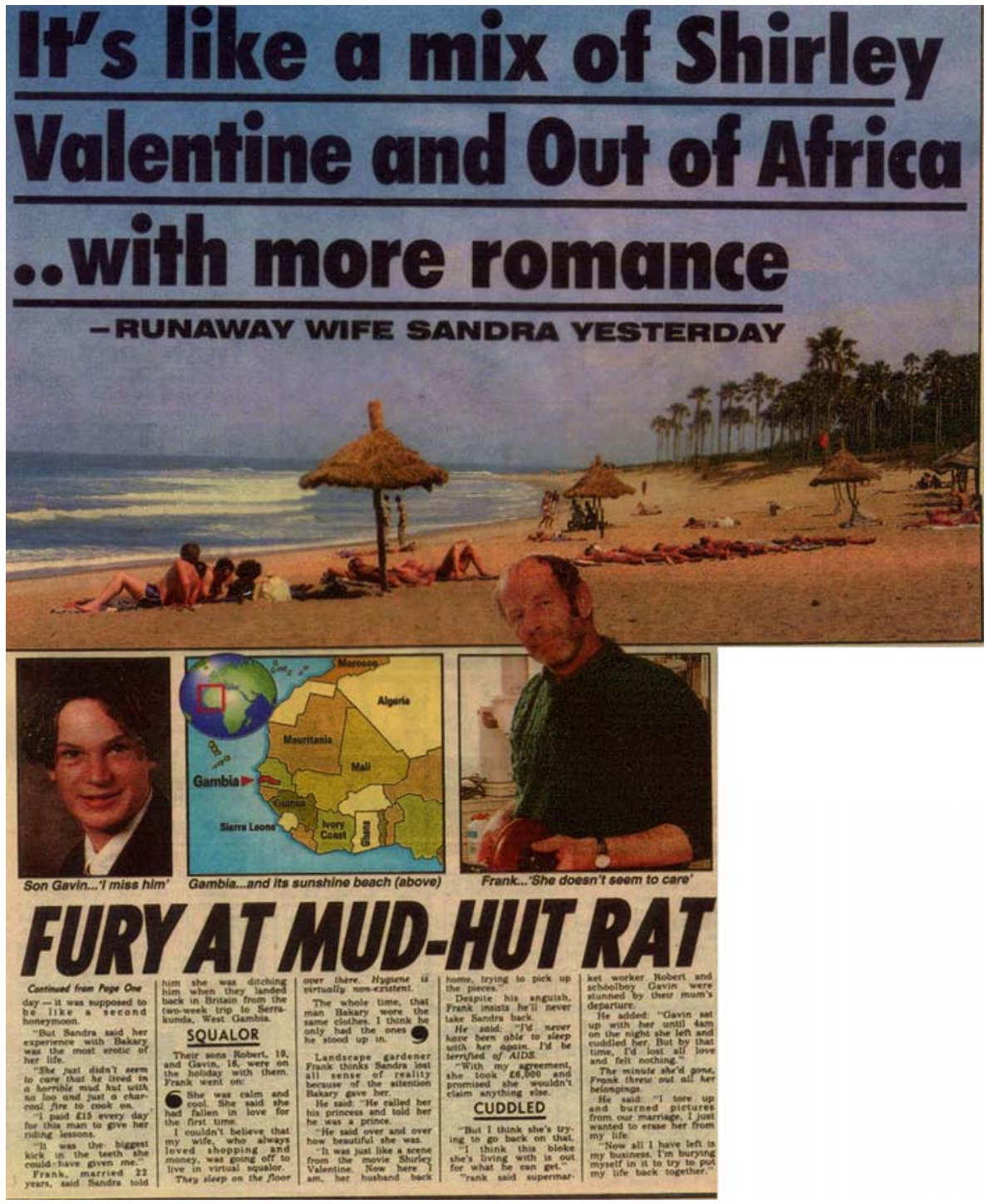

Fig. 2 Page 5 of the Sun for Monday $7^{\text {th }}$ February, 1994, continuing story begun on the front page, using colour photographs and illustration. 


\section{Princely Contrasts}

As Bakary was neither visually nor vocally given presence in the article, he was discussed and so known about only through quotations from the two other protagonists and through the story as a whole put together by the reporter. The quantity of statements from the white protagonists in this triangle of relationships was also rendered insignificant in light of the quality of what they said and how this was treated. The husband's commentary and evaluation was wholly negative throughout. This surrounded the largely positive commentary and evaluation of the ex-wife. It also made suspect the acknowledgement she offered of her drastic loss of material security and the comforts of suburban life in England, along with her expression of regret over leaving her two sons. At the third point of the triangle, the silence attached to the black person's participation in the story appealed only to speculation and fancy, stereotype and myth, markers of which were set down from the outset in the way he was identified and labelled. As well as being described as a 'mud-hut rat' who lived in 'virtual squalor', the 'black hunk' attribution drew directly on the racially stereotypical associations of black men with rampant libidos and an aggressive, insatiable sexuality. Throughout the story, a continual equation was made between, on the one hand, the exotic 'sex in the sand' (the other kind of 'riding lessons' implied in the narrative) and the 'primitive' material conditions in which it occurred, and on the other, between wanton lubricity and lack of moral scruples (Bakary was said to be 'out for what he can get', both from 'hubby Frank' as well as his now ex-wife). These were all part of the thematic pattern of contrasts in the story, which also included that set up between erotic love and motherly love (Sandra's sons were said to be 'stunned by their mum's departure' for a 'shack' in 'the middle of the Gambian bush'). The symbolic conjunction between sexual passion and racial atavism was then linked immediately to the price paid for this passion - the loss of modern civilisation.

The loss was indicated right from the start by the first-sentence description of Bakary as a 'native'. This is a term that comes laden with stereotypical associations, the term 'black native' even more so. The interpretative cues contained in such associations are always prescriptive for potential readings. In this case the term 'native' carries highly condensed notions of social backwardness and racial inferiority. These were first crystallised and widely distributed during the period of 'high' imperialism and colonialism when Britannia ruled the waves and much else besides. Those who live in the little England of the shires do not of course belong to the category 'native'. We would only refer to the 'natives of Leominster' in an ironic or facetious sense, and certainly not in the same sense associated with Gambia or most other African nations. 'Natives' are always other people, never 'us'. The term is an ideological device for distancing 'us' from 'them' and designating 'them' as the primitive Other, as in the case of this tribal African prince. The term is self-validating: it confirms 'us' in 'our' position of civilised order, economic prosperity and technological advance.

Here is where the intertextual relevance of the other front page story on this edition of The Sun becomes abundantly clear (see Fig. 1). To the left of the main story and immediately adjacent to it was a story about another prince, but not an African one. The story concerned a real prince, a bona fide prince who is linked by blood to a long line of aristocratic breeding. The juxtaposition may appear quite fortuitous, but it clearly set up certain ideological relations across the two stories, particularly as their being placed side by side invited readers to attend to one immediately following the other. These relations were based around a further set of binary contrasts. The story about Prince Charles concerned the occasion in Australia when a student fired two shots from a starting pistol while the heir to the British throne was presiding over an awards ceremony. The English prince was described as reacting with measured dignity and calm, with the sang froid befitting a member of the nobility. The 'ice-cool' demeanour he maintained in the face of this 
apparent attack was attributed to his 'royal blue blood'. He was quoted as saying: 'A thousand years of breeding have gone into this, you know'. In this way 'our' prince, a royal emissary in a former colony that was once part of the glorious British Empire, was positioned as diametrically opposite in character and disposition to the African prince in the lead story. While the former was

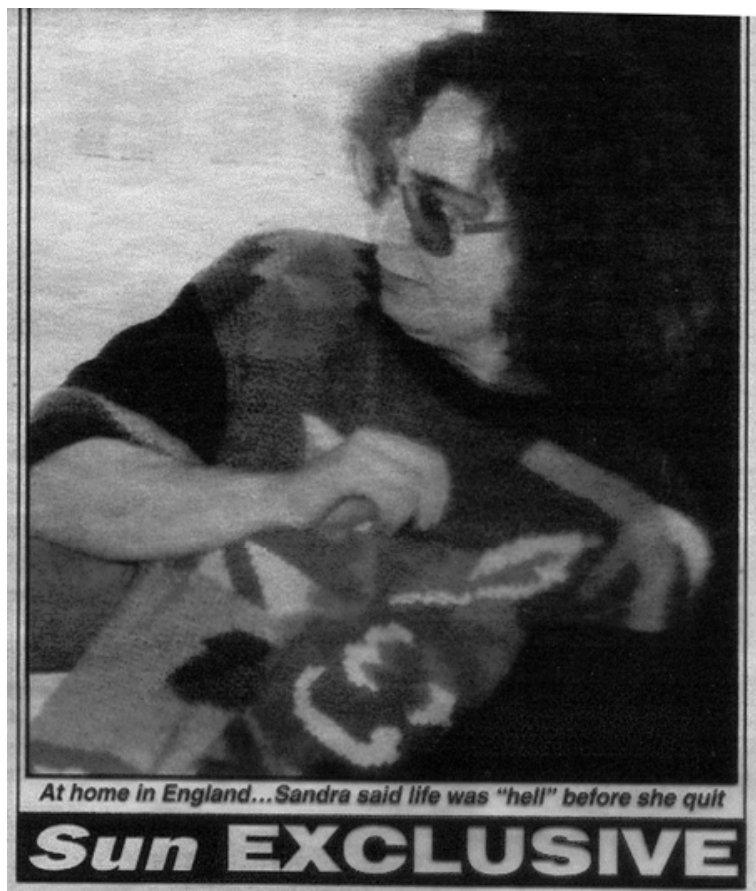

RUNAWAY mum Sandra Anderson spoke for the first time of her exotic aftair and said: "it's like a mix of Shirley Valentine and Out of Africa - with more remanoe,"

Stirring a pot on an open fre outside Stirring a pot on an open fire outside the shack she now call.
home, she added: "I'm so happy. I've never really been happy before but this is like paradise on earth." really been happy Sandra, 39, moved into African prince Sagnia Bakary's spartan
shack a month ago after leaving her family in Leominster, It is set in the middle of the Gambian bush about 15 miles from the coastal resort of Sarrakunda. The hut has no running water and the loo is a hole in the ground But Sandra insisted:
It's better than a nve "Il's better than a nve
star hotel.
ules basie, there's open cesspit in the
garden but I'm happy." My husband Frank Hes a very dimeult man to live with, but Brilliant

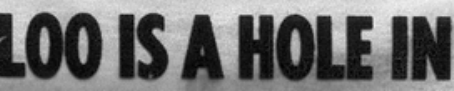
GROUND BUT I'VE FOUND PARADISE Frank never bothered
bout me at all - he just took me for grante and kept telling me Baks makes me feet hee a real woman. 1 we lost a stone since $I$ ' been here-eating well the sunshine and all the you know what 1 mean Baks is a brilliant
over. For the frst time in my life I've got man who actually both and worries about me in Frank never did an 1 enjoyed. Now it's wonderful, hed I had made cally - it's heaven. The minute I sew beach towards me on the nirst day of our
He treated me so well, was so courteou knew he was the man Dreamed Now we're running a riding school together happier. T've alwaus dreamed of being whisked awoay in the sunshine by a ma happened.

1 Just can't believe and have to pinch my. self every morning to Sandra's only regret is sons Robert and Gavin. She said: ${ }^{\prime} 1$ miss write so them all the Hive told them they're welcome $t$ here. and I do intend on a horse and now it's being separated from described as behaving with impeccable 'good breeding', the latter was shown as hedonistic, unscrupulous and dishonourable. 'Stealing' someone's wife and committing adultery could of course have been constructed as parallel narratives for both princes, but exactly the opposite ideological 'effect' was achieved. There are Princes and princes, and what the putative difference symbolises is a longestablished and enduring racial superiority.

Fig. 3 Monochrome inside section of the Sun's lead story for Monday $7^{\text {th }}$ February, 1994, giving the woman's version of events.

\section{From Hell to Paradise}

There is another side to this stereotypical construction. To see it we need to return to the statements made by the 'runaway mum'. While these were set up to be interpreted through the negative frame already established in the accusatory statements made by her husband, Sandra (unlike her new lover) was given considerable space to explain the reasons for her precipitous shift from English suburbia to African bush. She does this through a further set of contrasts between her old life of marital misery and her new life of extra-marital bliss: 'I've never really been happy before but this is like paradise on earth'. Sandra's declaration was prefaced by a description of her 'stirring a pot on an open fire outside the shack she now calls home'. The pejorative description and the direct quotation may seem to run counter to each other, with the weight of evidence falling on the extent to which Sandra had socially descended, but in the caption to an inside photo-image, she was also cited as saying that 'life was "hell” before she quit'. The image showed her with her arm raised, as if in self- 
defence. It is unclear if this is connected with the caption, but it is absolutely clear that she viewed her transition as moving from 'hell' to 'paradise' in one fell swoop. What she had lost in the life she left behind was of little consequence compared with what she had gained in the life she was now entered upon. Whereas her husband 'took me for granted and kept telling me I was worthless', Baks 'treated me so well, was so courteous and a real gentleman'. She was said to 'feel like a princess'. A 'princess in paradise' may not be expected to cook with a single pot on an open fire, never mind shit into 'an open cesspit in the garden', but the prevailing reference was to how she felt and to her newfound fulfilment and happiness.

The disparity was given especial attention in the secondary headline on page four: 'Loo Is A Hole In Ground But I've Found Paradise'. The theme of transition-as-descent was reversed. A hole-in-the-ground toilet may have sounded more like paradise lost than paradise gained, and this was clearly the gloss put upon affairs by the jilted husband. Despite being framed by the sequencing of their two 'voices', Sandra's emphasis on her feelings of love and satisfaction posited indubitable gain rather than loss. The theme thus changed to transition-as-ascent, from 'hell' to 'paradise', in a way that suggests a different source of appeal in the parable, one perhaps especially felt by women who were 'taken for granted' or worse, made to feel 'worthless' by their partners. The appeal was at once emotional and sexual, deriving from the respect and courtesy accorded to her by her new lover, and from the sexual passion she was enjoying for the first time in her life - 'Baks is a brilliant lover'; he 'makes me feel like a real woman'. Sandra coyly mentioned losing weight because of eating well and 'all the exercise I'm getting, if you know what I mean'. She was 'totally happy for the first time'. Again, the contrast was with her previous love of 'shopping and money', implying that consumerist investments and chasing after happiness in commodities were poor substitutes for being made to feel 'like a real woman'.

The contrast is a commonplace one in popular culture. Given that in this case it was struck between a simple fulfilling life in the sun and an empty, unsatisfying suburban lifestyle worn down by mortgage worries, humdrum routine and the weight of middle age which two grown-up sons served to confirm, it is no surprise that Sandra compared what had happened with the narrative of the film Shirley Valentine, released four years earlier and starring Pauline Collins. So too did Frank, but his reference was to the self-serving flattery of Sagnia Bakary (his counterpart in the film being Costas, Shirley's Greek lover, played by Tom Conti). Frank regarded his exwife as having 'lost all sense of reality because of the attention Bakary gave her'. That is why for him it was 'just like a scene from the movie Shirley Valentine'. He contrasted this with his own situation as 'her husband back home, trying to pick up the pieces'. His ex-wife clearly invested a different set of feelings in the comparison, and she also compared her affair with Out of Africa, the 1985 Oscar-winning film starring Meryl Streep and Robert Redford. This was based on the passionate love affair in Kenya between Karen Blixen (1885-1962) and Denys Finch Hatton (1887-1931), big game safari hunter and son of the Earl of Winchilsea. Sandra considered her love affair as 'like a mix of Shirley Valentine and Out of Africa - with more romance'. Such analogies in quotations from participant sources in news narratives show how much films provide significant reference points in everyday life, regardless of whether they denote aspects of similarity or dissimilarity. In the story they clearly denoted both. For Frank the comparison was with loss of reality, reinforcing the notion of film as fiction, offering make-believe worlds that diverge from the necessary actualities of ordinary social life - in this case, romance in the negative sense. Sandra by contrast used the term romance in a positive way; her own new life resembled a love story in the cinema but was superior because it provided even 'more romance'. Her sense of romance was nevertheless rooted firmly in cinematic references: 'I've always dreamed of being whisked away in the sunshine by a man on a horse and now it's happened'. Romance and reality had converged. 
Comparisons between films and events in people's personal lives hinge around these ambiguities of meaning and value, switching between film as cinematic illusion and film as naturalist representation, film as unreal and film as capturing the dramatic reality of interpersonal relationships and the collision of different needs and imperatives, different hopes and desires, and different ways of seeing and accounting for what has happened. So, for example, Frank confined his comparison to Shirley Valentine, not because it involves the return of a somewhat chastened wife (Frank declared he would not take her back because of fear of HIV/AIDS) but because it depicts a sexually opportunist, morally unscrupulous, foreign lover. Similarly, Sandra's reference to Out of Africa spoke to her own situation in at least two ways. Karen Blixen/Isak Dinesen wrote passionately and without sentimentality of the Kikuyu and her life in the Ngong Hills of Kenya in her autobiography Out of Africa (1971), but never attained the same objectivity when writing about her fabled lover, Finch Hatton, who she depicted as a model of male perfection. 'He is always presented by her as a god, who swoops from the sky in his little aeroplane bearing happiness' and possessing 'a powerful, wide-ranging mind and natural authority' (Amory, 1981; see also Trzebinski, 1977 and Wheeler, 2006). ${ }^{4}$ The parallel in the heroic way Sandra portrays her new lover is clear, but there is another parallel in the abandonment not only of life in civilised Europe but also in Sandra's rejection of bourgeois respectability. Karen Blixen wrote to her Aunt Bess (Mary Bess Westenholz, 1857-1947) that 'there is so much in life to love, so much to live for, that to me there is something blasphemous about this monopoly of love and cooperation between human beings by marriage and family life' (Dinesen, 1981: 394). Such monopoly relates to bourgeois standards and ideals, and it is these Sandra has turned her back on.

\section{Populist Primitivism}

It could be said that this tabloid news story also dealt with this drama and the divergent paths that had split open a longstanding marriage, but in line with the Sun's general 'conservative articulation of de-subordinate impulses', it did not question or challenge the social conventions regarding marriage and family life, particularly as they affect women (McGuigan, 1992: 185; see also Miliband, 1978). Its treatment of the triadic set of relationships in the story worked within the bounds of normality and even more significantly, through the reproduction of various racial myths and stereotypes. ${ }^{5}$ The myths and stereotypes were both social and sexual. All the details surrounding the polar opposition between the comfort and security of suburban England and the crude living arrangements in the Gambian bush played on the stereotypical civilised/primitive divide that grew up in the later nineteenth century and is an enduring legacy of Victorian racism and imperialism. In contrast to earlier distinctions, this divide has operated to anachronistically position Africa and African people over against Europe and Europeans and to symbolically place them on an evolutionist scale of social development and progress with the former representing backwardness and stagnation and the latter enterprise, achievement and innovation. The many diverse ways of life in the African continent were long thought of as those of 'people without history'. This belief found its latter-day counterpart in Sagnia Bakary's 'person without voice' his routine exclusion from the accounts that count.

\footnotetext{
${ }^{4}$ Finch Hatton took up flying in 1929 and bought a Gypsy Moth airplane a year later. It was in this plane that he crashed fatally in 1931. As Christopher Ondaatje (2006) noted in a review of her book, Sara Wheeler 'silently corrects' Robert Redford's 'grossly inaccurate portrait of Finch Hatton' in the film. Isak Dinesen was the pen name of Karen Blixen.

${ }^{5}$ This article focuses on the ideological consequences of these myths and stereotypes rather than the extent to which the content of the story did or did not correspond with the events. Any embroidery of the facts of the case is not strictly relevant to this primary analytical focus.
} 
The unequal axis of the imperial relation was reproduced in the confinement of narrative voices to a male/female dyad that consolidated the sense of white priority and superiority. The opposition of female and male viewpoints set up by the story was that between romantic happiness and sexual fulfilment, and suburban prosperity and conjugal obligations. This was mapped onto the civilised/primitive dichotomy in such a way that maleness was made to uphold a sense of adhering to reality and femaleness a sense of losing touch with reality. The 'normal' husband was also counterposed to the 'wayward' wife and 'native' hunk in such a way as to reproduce the old notion of 'going native', making that precipitous leap across the civilised/primitive divide. If that leap has usually created fears and anxieties in the bourgeois breast, these have been accompanied by their shadow fears and anxieties, coalescing around the doubt that civilised life may be deficient in certain ways, and lacking in something vital, such as adventure, passion, risk. This is acknowledged in the story, for Sandra was allowed to contrast the previous deficiencies in her life with her then current sexual and romantic happiness. To attain such happiness, she had been willing to sacrifice her settled nuclear family set-up and turn her back on the past. Despite the basic material conditions of her new life (albeit stereotypically portrayed) she had discovered and attained what was previously absent in her life.

The Sun's story did not openly side with either the man or the woman, but it did give priority to the man's account and allowed it normatively to mediate and position the woman's account. The two accounts did not count in the same way. Their inclusion invited alternative readings but at the same time rendered one less compelling in the stakes of credibility, never mind less commanding in the scales of responsibility. The power of the story's rhetorical organisation is that it appeared to offer equal space to both accounts while ensuring that the conventional white male viewpoint prevailed. In doing this it depended ideologically on a white/black male contrast that drew implicitly on some of the key stereotypical notions of biological racism. The problem of the late-twentieth century was still the problem of the colour line, and the racism at the core of that problem continued to be infused with sexual apprehensions and anxieties. 'From New Orleans to New Guinea, from Barbados to Bulawayo, from Kimberley to Kuala Lumpur, the quintessential taboo to be explained is the white man's formal objection to intimacy between black men and white women' (Hyam, 1992: 203). ${ }^{6}$ Such a taboo no longer formally exists and cannot be justified on any official grounds, but that does not mean that the objection, or the white male insecurities and fears on which it rests, no longer apply. News stories like the Sun's play on and help perpetuate, in however covert or attenuated a fashion, mythical notions not only of black men having larger penises than white men, but also having a higher sex drive and greater sexual staying power. Along with this erotic privilege has been a compensating, but equally mythical notion of black racial inferiority on the grounds of lower intelligence, reduced powers of rationality, hedonistic impulses and lack of restraint, discipline and ambition. Sexual prejudices are often closely interwoven with racial antagonisms. Open expression of such antagonisms in the popular press of the early 1990s was less acceptable than it had previously been, but obviously this did not prevent their ideological rationale continuing to be given clear articulation. Myths that help ground nationalist legitimacy and ensure social reproduction often show remarkable persistence. This again is where cross-narrative interaction is important.

All newspapers are mosaics of narrative and representation whose different elements appear formally unrelated to each other, yet at the same time they are composed both on single pages and as a whole, and subject to various editorial decisions that are driven by particular news values and broader commercial imperatives. This may mean that interpreting the Sun's advert for its Snakes and Ladders scratch-card game, which was placed immediately above the Mud-Hut Rat story in

\footnotetext{
${ }^{6}$ On sexual relations between white and black men and women in North America in the postwar period, see Hernton, 1970 and Day, 1974.
} 
the top half of the front page, as bearing sexual metaphors and allusions to the rungs of civilisational progress, is to find evidence of intertextual relations that would hardly register with the majority of its readers. This is not the case with the two lead stories. Both were about princes, of alleged or proven royal descent, and so directly invited comparative assessment. Sandra Anderson referred to Sagnia Bakary as 'a real gentleman', yet the strategic contrasts and oppositions in the narrative as a whole seemed to support retention of the view, developed from the mid-nineteenth century, that white skin was 'an essential mark of a gentleman' and that 'even “a self-improved Negro” could not rise to the elevated status of a gentleman' (Lorimer, 1978: 15). The paradise-from-hell trajectory ran in a contradictory direction to the theme of downward social mobility, and so may have lent support to the claim that the 'tribal prince' was indeed 'a real gentleman', but the possibility of this was seriously weakened by the Sun's reminder of what real gentlemanly status entailed - a thousand years of all-white racial breeding and the aristocratic attributes of calm dignity and 'natural authority' that go with this. These could not be shown to be as clearly apparent in the heartbroken businessman/husband. The necessary comparison lay readily to hand in the Prince Charles story. For once it was his good repute rather than his risible foibles that was being foregrounded in Britain's best-selling newspaper.

Primitivism has always played fear and fascination ambivalently off against each other, whether in high cultural modernism or popular music and dance, with the appeal being either to a temporary or a more durable reaction against conventional social values. The Sun story offered both these dimensions of primitivism and so allowed its readers to ask projective 'what if' questions, but not in the end at the expense of a balanced choice of sympathy for the two antagonists. The man's situation was given preferential treatment as heartbreak and betrayal, and the women's exploits were seen through a white erotic imaginary. This in turn revolved around the lack of established English social norms which the narrative served to endorse. Invoking an engrained sense of hierarchical ethnic classification, the story took perceived sexual infraction as the chief vehicle for re-establishing their legitimacy. In doing so this late-twentieth century sample of populist primitivism demonstrated the resilience of racial stereotypes which, despite their imperial and colonial origins, seemed to retain the strength of their pernicious notions in a new historical context. It showed how such stereotypes can still be made to 'fit the moment' when black/white interethnic relations are no longer the sexual taboo they have previously been. The primitive black stereotype has always been an ideological construct, and the outcome remains the same. Perpetuating the myth of the primitive black Other relies on the continuance of racist images that not only demean its stereotyped objects but also relegate them to silence, and symbolically exclude them from the order of civilised society.

\title{
References
}

Allport G 1954 The Nature of Prejudice Cambridge MA Addison Wesley

Amory M 1981 ‘The African Queen’, review of Dinesen 1981 Sunday Times 13 September.

Bhabha H 1997 The Location of Culture London and New York Routledge

Blizen K 1971/1937 Out of Africa London Jonathan Cape.

\author{
Chippindale P and Horrie C 1990 Stick It Up Your Punter! The Rise and Fall of the Sun \\ London Heinemann
}


Day B 1974 Sexual Life Between Blacks and Whites London Collins.

Deacon D Pickering M Golding P and Murdock G 2007 Researching Communications: A Practical Guide to Methods in Media and Cultural Analysis ( $2^{\text {nd }}$ edition) London Hodder Arnold.

Dinesen I 1981 Letters from Africa 1914-1931 London Weidenfeld and Nicolson.

Hernton C 1970 Sex and Racism London Paladin.

Hinton P 2000 Stereotypes, Cognition and Culture Hove Psychology Press

Hyam R 1992 Empire and Sexuality Manchester and New York Manchester University Press.

Lorimer D 1978 Colour, Class and the Victorians Leicester Leicester University Press.

McGuigan J 1992 Cultural Populism London and New York Routledge

Miliband R 1978 ‘A State of De-subordination’ British Journal of Sociology 29/4

Ondaatje, C. (2006) 'Animal Passion Flies High Above the Serengeti’, Times Higher, 7 April.

Pickering M 2001 Stereotyping: The Politics of Representation Basingstoke and New York Palgrave Macmillan.

Pickering M 2004a 'The Inescapably Social Concept of Stereotyping' in Barker A ed. The Power and Persistence of Stereotyping - O Poder e a Persistência dos Esteriótipos Aveiro Universidade de Aveiro 21-32.

Pickering M. 2004b 'Racial Stereotypes' in Taylor G and Spencer S eds Social Identity: Multidisciplinary Approaches London and New York Routledge 91-106.

Pickering M 2007 'Stereotypes and Stereotyping' in Ritzer G ed. Blackwell Encyclopedia of Sociology 10 vols Vol X 4773-8.

Trzebinski E 1977 Silence Will Speak: A Study of the Life of Denys Finch Hatton and his Relationship with Karen Blizen London Heineman

Wheeler S 2006 Too Close to the Sun: The Life and Times of Denys Finch Hatton London Jonathan Cape 